\title{
Investigations of Flame Retardant Properties of Zinc Borate Accompanying with Huntite and Hydromagnesite in Polymer Composites
}

\author{
Hüsnügül YILMAZ ATAY ${ }^{1)}$, Öykü İÇİN ${ }^{2)}$ Buket KURU ${ }^{1,3)}$
}

\footnotetext{
1) İzmir Katip Çelebi University, Department of Material Science and Engineering, 35620 Çiğli İzmir Turkey, Assoc. Prof. Dr.; email: hgulyilmaz@gmail.com

2) İzmir Institute of Technology, Department of Material Science and Engineering, 35430 Urla İzmir Turkey, Graduate Student; email: oyku_icin882@hotmail.com

3) Budin Kimyevi Maddeler San ve Tic. Lim. Şti. AOSB, 35620 Çiğli İzmir, Graduate Student; email: bukettkuru@gmail.com
}

http://doi.org/10.29227/IM-2020-01-13

Submission date: 11-01-2020 | Review date: 02-04-2020

\section{Abstract}

Fires have been a danger to human beings for the centuries. As people lost their lives and property in fires, they tried to fight the fire and their efforts in this area continued increasingly. Unfortunately, it is still not possible to completely reset the risk of starting the fire. But it seems likely to extinguish immediately after the fire has started, and this is very important to save people's lives. Scientists have been working in this field in recent years; they are concentrated on producing fire-resistant materials using different materials. This can be provided by different ways; either fire-resistant material can be produced new, or the fire resistivity can be provided by incorporating the additive material into a flammable material. In our previous studies, we used huntite and hydromagnesite minerals to give fire resistance property to polymer materials, very successful results were obtained. In this study, huntite and hydromagnesite minerals were used for accompanying with zinc borate in polypropylene composites in order to increase the flame retardant property of a polymeric materials. Different content of minerals were blended with polypropylene, and composites were produced by twin-screw extruder for observing synergistic effect. Scanning electron microscopy (SEM) analyses were conducted to determine the structural and morphological properties of the composites. Thermal properties were determined according to thermogravimetric analysis (TGA). Tensile and three point bending tests were carried out to obtain mechanical properties. Flame retardant performance was evaluated according to UL 94 vertically flammability test. It was concluded that very good synergistic effects were obtained that zinc borate was significantly influential with huntite/hydromagnesite in the flammability characteristics of composites because higher char formation is observed with zinc borate addtion. Moreover, the zinc borate reduced the smoke generated during combustion.

Keywords: flame retardancy, huntite hydromagnesite, zinc borate, polypropylene, mechanical properties, thermal degredation, synergistic effect

\section{Introduction}

Polypropylene (PP) is the most widely used commodity polymer in different commercial applications due to its good impact strength, good chemical resistance, good electrical insulation, low cost and easy processing. However, despite these wonderful features, PP is also known with its flammable property. Aliphatic hydrocarbon structure of this polymer gives rise to its severe flammability [1]. As pointedly, it should be investigated in order to enhance the usage of the polymer against fire to reduce losses of life and property [2-5]. With this regard, tendency of the addition of the flame retardant and the smoke suppressant additives has increased rapidly. Their effect is to drop off the chances of a fire starting with providing resistance to ignition. Even if ignition does occur, flame retardants can act to delay the spread of flame, provide extra time in the early stages so the fire can be extinguished or an escape can be made $[6,7]$.

Flame retardant additives are generally classified into two groups; halogenated and halogen free materials. Some halogenated ones are tris(2-chloroethyl) phosphate, tris(1,3-dichloroisopropyl) phosphate, pentabromobenzyl acrylate and tris(1-chloro-2-propyl) phosphate. Indeed, they are not very preferred in the recent times because they release toxic gas to the environment and they can affect the endocrine, immune, reproductive and nervous systems. Some animal studies have shown that long-term exposure to those flame retardants can lead to cancer [8]. Halogen free flame retardants, which involve phosphorus, nitrogen, silicone, boron, zinc, iron, and aluminum-containing materials are considered as non toxic and environmentally harmless. In order to increase flame resistivity of polymers, environmental friendly systems have been also favored lately [9-11].

Huntite $\left[\mathrm{Mg}_{3} \mathrm{Ca}\left(\mathrm{CO}_{3}\right)_{4}\right]$ and hydromagnesite $\left[\mathrm{Mg}_{5}\left(\mathrm{CO}_{3}\right)_{4}(\mathrm{OH})_{2} \cdot 4 \mathrm{H}_{2} \mathrm{O}\right]$ minerals are defined as a natural mixture and classified as salt type carbonate minerals. This naturally formed mineral is commercially mined and processed as an alternative to the commonly used flame retardants because of its attractive properties, such as low smoke generation, environmentally safe, halogen free, recyclable, noncorrosive, and low combustion. At present, economically important reserves of huntite and hydromagnesite are found in Turkey and Greece. Production facilities in Turkey have lowered the cost, improved quality control, and should further the use of these minerals. [12-16]. The thermal degradation of huntite and hydromagnesite gives off both water and carbon dioxide when heated, with a minor loss at about $230^{\circ} \mathrm{C}$, and major losses at about 420 and $550^{\circ} \mathrm{C}$ [17]. On the other hand, Zinc borate $(\mathrm{ZnB})$ that is an effective inorgan- 
Tab. 1. Designation and composition of PP and PP composites Tab. 1. Oznaczenie i skład PP i kompozytów PP

\begin{tabular}{|l|c|c|c|}
\hline Sample Code & $\begin{array}{c}\text { PP } \\
\text { (weight per cent) }\end{array}$ & $\begin{array}{c}\text { Huntite/Hydromagnesite } \\
\text { (weight per cent) }\end{array}$ & $\begin{array}{c}\text { ZnB } \\
\text { (weight per cent) }\end{array}$ \\
\hline PP & 100 & 0 & 0 \\
\hline PP80H10ZnB10 & 80 & 10 & 10 \\
\hline PP70H20ZnB10 & 70 & 20 & 10 \\
\hline PP60H30ZnB10 & 60 & 30 & 10 \\
\hline PP50H40ZnB10 & 50 & 40 & 10 \\
\hline PP40H50ZnB10 & 40 & 50 & 10 \\
\hline PP70H30 & 70 & 30 & 0 \\
\hline PP70ZnB30 & 70 & 0 & 30 \\
\hline
\end{tabular}
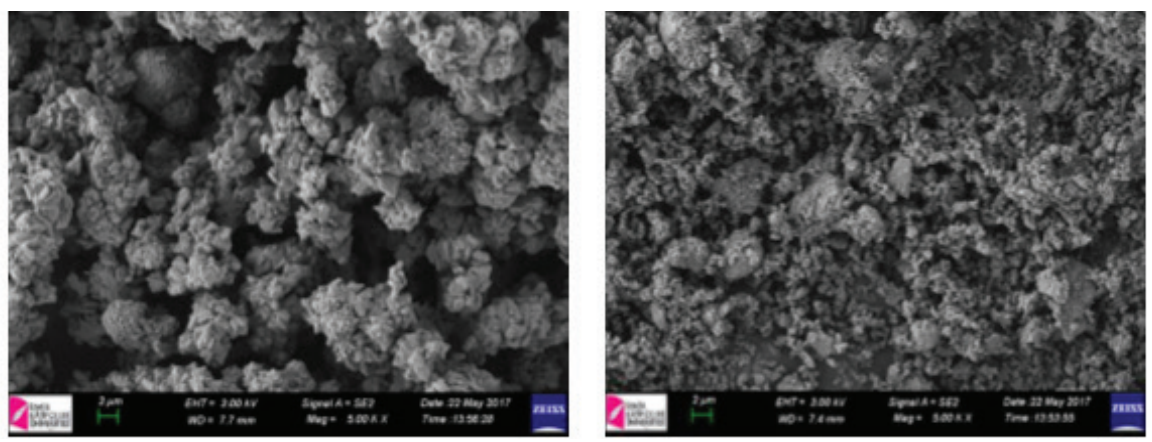

Fig. 1. SEM micrographs of the powders of (left) Zinc Borate and (right) Huntite/Hydromagnesite Rys. 1. Mikrografie SEM proszków (po lewej) boranu cynku i (po prawej) Huntite/Hydromagnesite

ic flame retardant additive is widely used both solely and in combination with other materials. Its influence as corrosion inhibitor, smoke suppressant, afterglow suppresant, synergistic agent improves elongation properties of polyoefins reported and emphasized by many authors [18-20].

To observe the synergistic effect with huntite and hydromagnesite and to increase the flame retardant property of the polymer composite, $\mathrm{ZnB}$ is used as a collateral additive in this study. Obtained samples were characterized by scanning electron microscopy (SEM) analysis to determine the structural and morphological properties of the composites. Tensile and three point bending tests were carried out to obtain mechanical properties. Thermal properties were determined according to thermogravimetric analysis (TGA). Finally, flame retardant performance of samples were observed according to UL 94 vertically flammability tests.

\section{Experimental Section}

\subsection{Materials}

Polypropylene (PP) pellets were used as a main polymer matrix, were supplied by Petkim Petrochemical Co. (Izmir, Turkey) with the melt flow index of $4.7 \mathrm{~g} / 10 \mathrm{~min}$ (MFI; $230^{\circ} \mathrm{C} / 2.16 \mathrm{~kg}$, ASTM D1238), melting point of $163^{\circ} \mathrm{C}$ and density of $0.905 \mathrm{~g} / \mathrm{cm}^{3}$. All the samples of natural huntite/hydromagnesite, which were used to improve flame retardancy properties of PP, were supplied from Tirtar region of Isparta. Commercial zinc borate was supplied by MELOS A.S. to increase flame retardancy properties of PP with huntite and hydromagnesite and its particle size range from 5 to $45 \mu \mathrm{m}$.

\subsection{Sample Preparation}

Polypropylene based composites containing huntite/ hydromagnesite and zinc borate additives were produced by us- ing twin-screw extruder (co-rotate) (Labtech) with L/D ratio of the $44: 1$ at rpm. Screw speed was adjusted as $190 \mathrm{rpm}$ and zone temperatures of extruder were selected between the temperatures $170^{\circ} \mathrm{C}$ and $185^{\circ} \mathrm{C} .0,10,20,30,40,50 \mathrm{wt} \%$ huntite/hydromagnesite and 10, $30 \mathrm{wt} \%$ zinc oxide reinforced PP composites were manufactured to observe synergistic effect (Table 1).

The samples for thermal, mechanical and flammability tests were produced by using laboratory scale press (Hydraulic Laboratory Press, Labtech) which was heating and cooling platens at $200^{\circ} \mathrm{C}$ for $9 \mathrm{~min}$. according to ISO R 527 and ISO 178 , respectively.

\subsection{Characterization of Composites}

The surface morphology and microstructure of $\mathrm{ZnB}$, huntite/hydromagnesite and composite samples were characterized by a scanning electron microscope (SEM, Zeiss Sigma 300 VP-FESEM). Thermal properties of the all composites were investigated by TGA analyzer (Perkin Elmer, STA 8000 ) by heating from room temperature to $600^{\circ} \mathrm{C}$ at a heating rate of $10^{\circ} \mathrm{C} /$ min under nitrogen atmosphere. Tensile testing samples were obtained by using a mold which cut the plate with blades according to ASTM D638 standard. Tensile properties were tested by using tensile test machine (SHIMADZU, AGS-X $5 \mathrm{kN}$ ) with a crosshead speed of $50 \mathrm{~mm} / \mathrm{min}$. The flexural modulus and flexural strength of samples were tested by test machine (SHIMADZU AGS-X 5kN) which involves a three-point bending tests at a crosshead speed of $1 \mathrm{~mm} / \mathrm{min}$ according to DIN EN ISO 178. Vertical burning test (UL 94) were conducted to investigate the flammability properties of composites on the test bars of $125 \times 13 \times 3.2 \mathrm{~mm}^{3}$ angular radius $1.3 \mathrm{~mm}$, according to American National Standard UL-94 standard.

\section{Results and Discussion}


Tab. 2. TGA results of the samples

Tab. 2. Wyniki TGA próbek

\begin{tabular}{|l|c|c|c|}
\hline Sample Code & $\mathbf{T}_{\mathbf{1} \%}\left({ }^{\circ} \mathbf{C}\right)$ & $\mathbf{T}_{\max }\left({ }^{\circ} \mathbf{C}\right)$ & $\begin{array}{c}\text { Char Residue at } \mathbf{6 0 0} \\
\text { (\%) }\end{array}$ \\
\hline PP & 416.80 & 451.06 & 1.32 \\
\hline PP80H10ZnB10 & 439.94 & 457.89 & 14.89 \\
\hline PP70H20ZnB10 & 425.50 & 459.94 & 21.26 \\
\hline PP60H30ZnB10 & 438.46 & 461.25 & 25.05 \\
\hline PP50H40ZnB10 & 434.70 & 456.07 & 28.72 \\
\hline PP40H50ZnB10 & 431.35 & 452.44 & 35.56 \\
\hline PP70H30 & 435.14 & 456.57 & 15.23 \\
\hline PP70ZnB30 & 422.69 & 446.71 & 25.32 \\
\hline
\end{tabular}

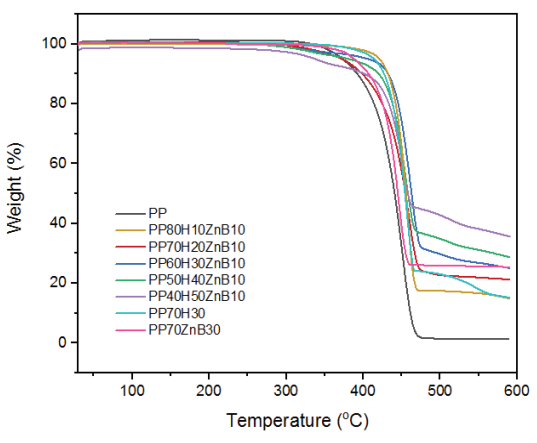

Fig. 2. TGA curves of the samples

Rys. 2. Krzywe TGA próbek

Fig. 1 shows the SEM images of $\mathrm{ZnB}$ and huntite/hydomagnesite powder. As can be seen from the Fig.1-a that the particle size of $\mathrm{ZnB}$ is in between 5-10 micron; however, there seems also some aglomeration. Huntite/hydromagnesite particles change from 1 to 10 micron. To prevent aglomeration, some deflocculating materials can be used.

Fig. 2 shows the detected TGA curves of the samples. The initial degradation temperature $\left(\mathrm{T}_{10 \%}\right)$, the maximum degradation temperature $\left(\mathrm{T}_{\max }\right)$ and the char residue values of $\mathrm{PP}$ and PP composites at $600^{\circ} \mathrm{C}$ are shown in Table 2. Degredation temperature for polypropylene matrix starts at $416.80^{\circ} \mathrm{C}$ and ends at $451.06^{\circ} \mathrm{C}$. Initial degradation temperature of PP matrix was retarded approximately $15^{\circ} \mathrm{C}$ by adding maximum amount of huntite/hydromagnesite (50\%) and $10 \%$ Zinc Borate. Moreover, it is seen in Fig. 2 and Table 2, increasing percentage of additives increases char residue. Maximum degradation temperature of the composites alters at the higher temperatures compared with pure PP, because of char layer formed by flame retardants. Therefore, PP matrix is protected from heat and combustion [21]. $\mathrm{PP} 70 \mathrm{H} 30$ and $\mathrm{PP} 60 \mathrm{H} 30 \mathrm{ZnB} 10$ have $435.14^{\circ} \mathrm{C}$ and $438.46^{\circ} \mathrm{C}$ initial temperature of the sample's decomposition process. $\left(\mathrm{T}_{1 \%}\right)$, respectively. The difference of the initial degradation temperature between PP70H30 and PP60H30ZnB10 shows that synergistic effect of zinc borate on huntite/hydromagnesite reinforced PP.

Tensile strength, Young's modulus, Flexural strength and modulus values of the samples are listed in Fig. 3 and Table 3. It can be seen that the tensile strength and strain properties were deteriorated by increasing huntite/hydromagnesite mineral quantity. Tensile strength of the pure PP was 35.28 $\mathrm{MPa}$. The values were estimated as $24.81 \mathrm{MPa}, 28.48 \mathrm{MPa}$, $28.00 \mathrm{MPa}, 25.22 \mathrm{MPa}$ and $21.22 \mathrm{MPa}$ with regard to $10 \%$, $20 \%, 30 \%, 40 \%$ and $50 \%$ of huntite/hydromagnesite and zinc borate addition, respectively. This decreasing is related to the poor compatibility between filler and polymer matrix which can be improved by the use of filler surface treatment [26]. In the tensile elongation results, it was obtained that increasing amount of mineral powder decreased the tensile elongation of PP by $91 \%$; strain value of pure PP is $20.76 \%$ and $1.10 \%$ for PP40H50ZnB10 $[26,27]$. The plastic deformation of the polymer matrix and isolated filler particles are related to poor adhesion, which is directly related with the decrease of elongation for the samples with higher filler content [22]. In addition, agglomeration of the additives is another reason for deterioraiton of the mechanical properties due to the weakened interaction between the agglomerated filler and polymer matrix [23]. This interaction is hindered at higher amount additive contents, resulting in lower strength of the composites [24]. Elongation is inversely proportional to the modulus of a material $[28,29]$. Elastic modulus of pure PP is $0.996 \mathrm{GPa}$, while $\mathrm{PP} 40 \mathrm{H} 50 \mathrm{ZnB} 10$ is 2.257 , thus it is increased by $126 \%$. It is markedly improved by adding fillers that have higher stiffness than the matrix and are able to improve the modulus of composite to a polymer matrix [30].

If the comparision is made between huntite/hydromagnesite and zinc borate reinforced samples, it can be seen that there is no big difference in tensile strength and elastic modulus values, as PP70H30 has $24.52 \mathrm{MPa}$ while PP70ZnB30 has 23.43 MPa tensile strength, and PP70H30 has $1.480 \mathrm{GPa}$ while PP70ZnB30 has $1.389 \mathrm{GPa}$ elastic modulus. However, there is a big difference in strain values because $\mathrm{P} 70 \mathrm{H} 30$ has $2.62 \%$ while PP70ZnB30 has $13.67 \%$. Therefore zinc borate containing samples have higher ductility than huntite/hydromagnesite reinforced samples.

Flexural strength of pure PP is $44.53 \mathrm{MPa}$. It decreased with increasing huntite/hydromagnesite content as following; 


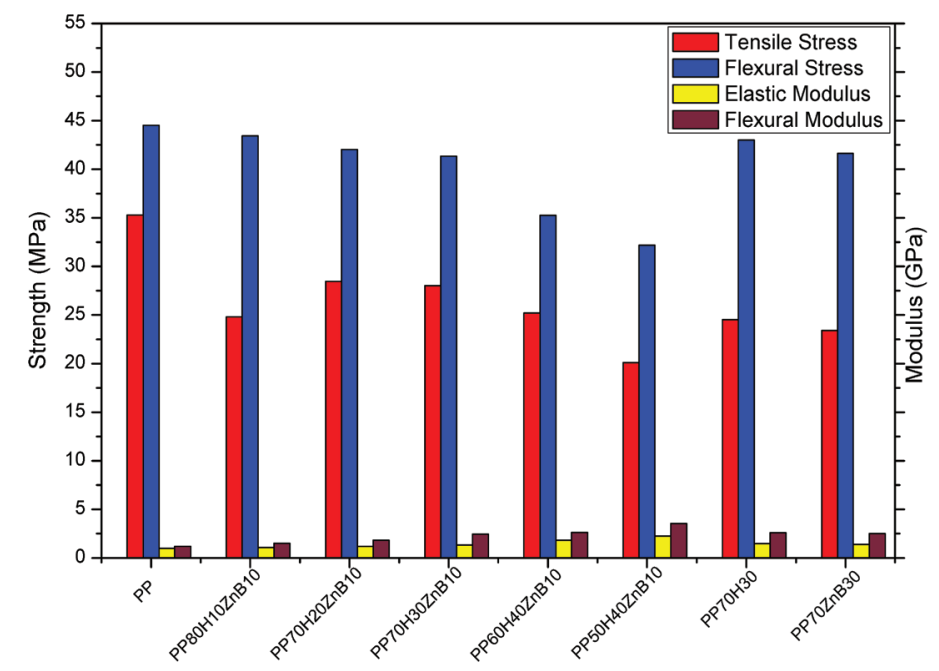

Fig. 3. Tensile\&Flexural Strength and Elastic\&Flexural Modulus of neat PP and composites

Rys. 3. Wytrzymałość na rozciąganie/wytrzymałość na zginanie i moduł sprężystości/na zginanie czystego PP i kompozytów

Tab. 3. Mechanical test results of the samples

Tab. 3. Wyniki badań mechanicznych próbek

\begin{tabular}{|l|c|c|c|c|c|c|}
\hline Samples & $\begin{array}{c}\text { Elastic } \\
\text { Modulus } \\
\mathbf{( G P a )}\end{array}$ & $\begin{array}{c}\text { Tensile } \\
\text { Strength } \\
\mathbf{( M P a )}\end{array}$ & $\begin{array}{c}\text { Tensile } \\
\text { Strain (\%) }\end{array}$ & $\begin{array}{c}\text { Flexural } \\
\text { Modulus } \\
\mathbf{( G P a )}\end{array}$ & $\begin{array}{c}\text { Flexural } \\
\text { Strength } \\
\mathbf{( M P a )}\end{array}$ & $\begin{array}{c}\text { Flexural } \\
\text { Strain (\%) }\end{array}$ \\
\hline PP & 0.996 & 35.28 & 20.76 & 1.197 & 44.53 & 7.46 \\
\hline PP80H10ZnB10 & 1.084 & 24.81 & 5.02 & 1.521 & 43.44 & 4.97 \\
\hline PP70H20ZnB10 & 1.196 & 28.48 & 4.36 & 1.815 & 42.03 & 4.94 \\
\hline PP60H30ZnB10 & 1.351 & 28.00 & 3.82 & 2.447 & 41.36 & 4.25 \\
\hline PP50H40ZnB10 & 1.828 & 25.22 & 2.04 & 2.615 & 35.26 & 3.66 \\
\hline PP40H50ZnB10 & 2.257 & 21.22 & 1.10 & 3.536 & 32.17 & 1.31 \\
\hline PP70H30 & 1.480 & 24.52 & 2.62 & 2.601 & 43.01 & 4.72 \\
\hline PP70ZnB30 & 1.389 & 23.43 & 13.67 & 2.520 & 41.62 & 4.45 \\
\hline
\end{tabular}

43.44 MPa, 42.03 MPa, 41.36 MPa, 35.26 MPa and $32.17 \mathrm{MPa}$ for $10 \%, 20 \%, 30 \%, 40 \%$ and $50 \%$ huntit/hydromagnesite content, respectively. $30 \%$ huntite/hydromagnesite and zinc borate added composite values are $43.01 \mathrm{MPa}$ and $41.62 \mathrm{MPa}$, respectively. It can be said that zinc borate has less effect on decreasing flexural strength value of PP than huntite/hydromagnesite filler. The highest huntite/hydromagnesite content is added into PP, the strain is decreased by $\% 82.4$. Flexural modulus is increased with the filler content from $1.197 \mathrm{GPa}$ for pure PP up to $3.536 \mathrm{GPa}$ for PP60H50ZnB10.

Fig. 4 represents the SEM micrographs of tensile fractured surfaces of PP based on the composites which are PP70H20ZnB10, PP60H30ZnB10, PP50H40ZnB10 and PP60H50ZnB10 composites. Morphology of samples was investigated by 1000 times magnification. Pure PP shows ductile behaviour. It is seen that the fractured morphologies of huntite/hydromagnesite and $\mathrm{ZnB}$ reinforced composites show resembling brittle failure by increasing amount of huntite. If SEM images of the samples of PP70H20ZnB10 and PP40H50ZnB10 are compared, it can be found out that $20 \%$ reinforced composite shows the ductile fracture surface which is seperated as fibers.

Flame retardant properties of specimens have been investigated by UL 94 vertical test method. Flame starting time, flame growing time, UL 94 rating and cotton ignition results of the samples are indicated in Table 4. Fig. 5 shows that photographs of the samples after UL 94 testing. Flaming time of all composite samples are higher than neat PP. The flame starting and growing times were delayed by 5 seconds with the addition of $\% 50$ huntite/hydromagnesite in composites. It can be seen that UL 94 rating is changed from V2 to V1 by increasing the amount of huntite/hydromagnesite from $20 \%$ to $30 \%$ in the composite. This result is consistent with the results found in the Ref [31] by $\% 50$ huntite/hydromagnesite addition to thermoplastic polyurethane, thus UL 94 rating was achieved as V1. The work principle of the additives is related with the dilution effect in gas phase by the help of water and $\mathrm{CO}_{2}$ release, endothermic decomposition and protective char layer $[12,21,31,32]$. On the other hand, the assistive effect of $\mathrm{ZnB}$ was observed, and this effect is considered that it is based on increasing barrier effect of char layer in the condensed phase and formation of incombustible gasses due to the acid base interactions. As mentioned Table 2, the char layer was $25.32 \%$ for the sample of PP70ZnB30 while it is $15.23 \%$ for PP70H30. Dike et al. [20] obtained the similar result of contribution of $\mathrm{ZnB}$ as synergistic additive for flame retardant in polymer.

\section{Conclusion}

Synergistic effect of $\mathrm{ZnB}$ on the flame retardant, mechanical and thermal properties of huntite/hydromagnesite reinforced PP composites were investigated. Composites were produced by using twin-screw extruder. SEM observations showed that there is no interaction between the flame retardant additives and polypropylene, except to mechan- 


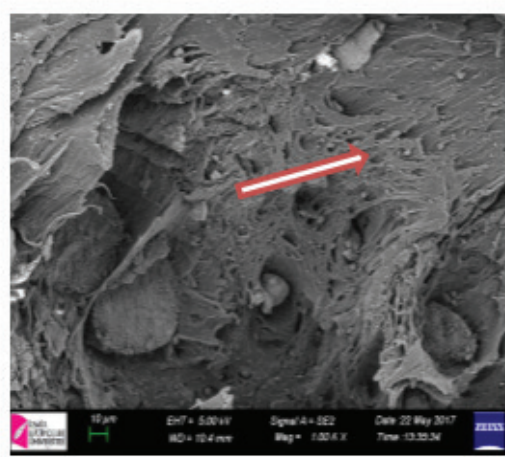

(a)

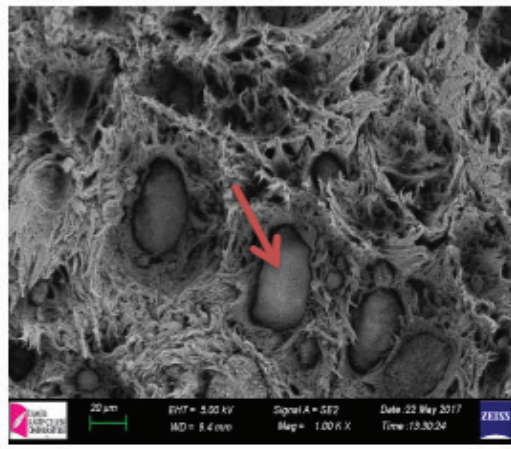

(c)

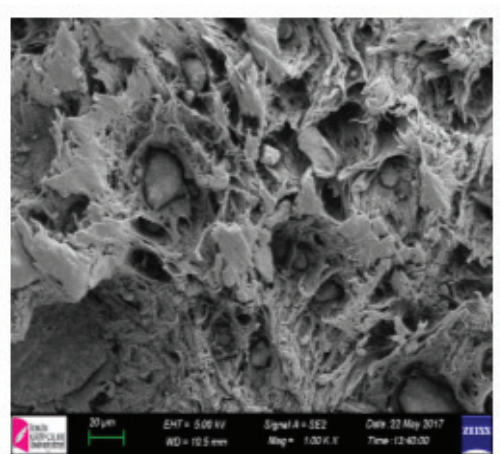

(b)

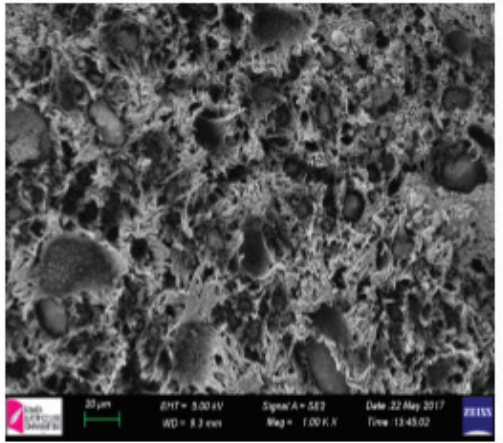

(d)

Fig. 4. SEM micrographs of (a) PP70H20ZnB10 (b) PP60H30ZnB10 (c) PP50H40ZnB10 and (d) PP60H50ZnB10 composites Rys. 4. Mikrografie SEM (a) PP70H20ZnB10 (b) PP60H30ZnB10 (c) PP50H40ZnB10 i (d) PP60H50ZnB10

Tab. 4. UL 94 Vertical test results of the samples Tab. 4. UL 94 Pionowe, wyniki badań próbek

\begin{tabular}{|l|c|c|c|c|}
\hline Samples & $\begin{array}{c}\text { Flame starting } \\
\text { time (s) }\end{array}$ & $\begin{array}{c}\text { Flame growing } \\
\text { time (s) }\end{array}$ & $\begin{array}{c}\text { UL 94 } \\
\text { (Vertical) rating }\end{array}$ & $\begin{array}{c}\text { Cotton } \\
\text { ignition }\end{array}$ \\
\hline PP & 5 & 8 & No rate & Yes \\
\hline PP80H10ZnB10 & 7 & 9 & V2 & Yes \\
\hline PP70H20ZnB10 & 8 & 10 & V2 & Yes \\
\hline PP60H30ZnB10 & 10 & 14 & V1 & No \\
\hline PP50H40ZnB10 & 12 & 14 & V1 & No \\
\hline PP40H50ZnB10 & 12 & 14 & V1 & No \\
\hline PP70H30 & 10 & 13 & V1 & No \\
\hline PP70ZnB30 & 10 & 12 & V1 & \\
\hline
\end{tabular}

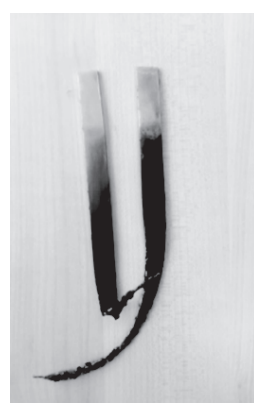

(a)

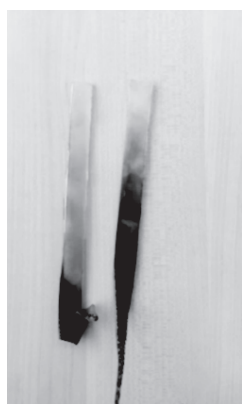

(b)

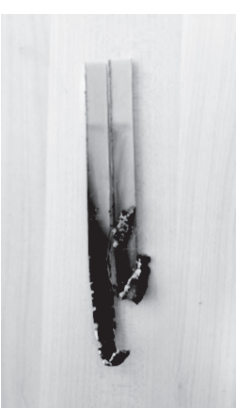

(c)

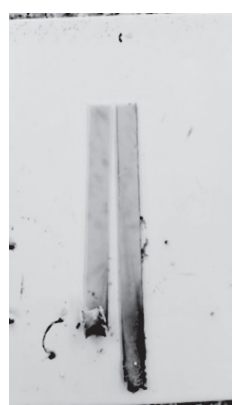

(d)

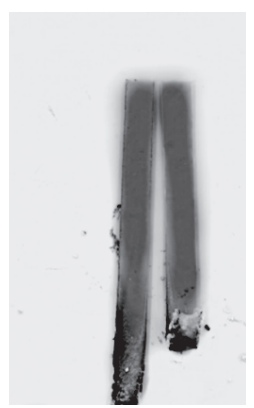

(e)

Fig. 5. Photographs of selected after UL 94 test sample of (a) PP (b) PP70H20ZnB10 (c) PP60H30ZnB10 (d) PP50H40ZnB10 and (e) PP40H50ZnB10

Rys. 5. Zdjęcia wybranych próbek testowych UL 94 (a) PP (b) PP70H20ZnB10 (c) PP60H30ZnB10 (d) PP50H40ZnB10 i (e) PP40H50ZnB10 
ical adhesion. Besides, fractured morphologies of huntite/ hydromagnesite and $\mathrm{ZnB}$ reinforced $\mathrm{PP}$ composites showed resembling brittle failure by increasing amount of huntite/ hydromagnesite in PP composite. According to TGA results, increasing addivite amount of minerals decreased the degradation weight. Addivite minerals increased the maximum degradation temperature compared to PP. Initial degradation temperature of polypropylene was increased approximately $15^{\circ} \mathrm{C}$ by the addition of $50 \%$ huntite/hydromagnesite and $10 \%$ Zinc Borate into PP matrix. Tensile strength and strain values of polypropylene composites decreased with increasing loading level. The tensile strength of PP was around $35 \mathrm{MPa}$. The highest loading of $50 \mathrm{wt} . \%$ decreased the tensile strength of PP to $21 \mathrm{MPa}$. However, elastic modulus was increased with the increasing huntite/hydromagnesite in polypropylene composites. Elastic modulus of PP was $1000 \mathrm{MPa}$ and the highest loading of $50 \mathrm{wt} . \%$ increased the elastic modulus to $2.3 \mathrm{GPa}$. Flexural modulus values were increased with the addition of mixtures of huntite/hydromagnesite into the polymeric matrix. The flexural modulus value of PP was around $1.2 \mathrm{GPa}$ and this was much lower than loading levels of 10 $20-30-40-50 \%$ by weight of huntite/hydromagnesite filled PP. UL94 vertical flammability test results showed that PP burned with melt dripping. 50\% huntite/hydromagnesite and $10 \% \mathrm{ZnB}$ reinforced polymer composites were much more succesful in burning test because fire starting time was higher. The addition of $\mathrm{ZnB}$ caused significant synergistic effect with huntite/hydromagnesite in the flammability characteristics of composites. Higher char formation is observed by zinc $\mathrm{ZnB}$ additon. In addition, it reduced smoke that generated during combustion.

\section{Acknowledgements}

The authors acknowledge to Budin Kimyevi Maddeler San ve Tic. Lim. Şti. and İzmir Katip Çelebi University Central Resarch Laboratories. 


\section{Literatura - References}

1. Bakar MB, Ishak MZA, Taib MR, Rozman HD, Jani MS. Flammability and mechanical properties of wood flourfilled polypropylene composites. Journal of Applied Polymer Science. 2010, 116, 2714-2722, DOI:10.1002/app.31791

2. Leong YW, Ishak ZAM, Ariffin A. Mechanical and thermal properties of talc and calcium carbonate filled polypropylene hybrid composites. Journal of Applied Polymer Science, 2004, 91, 3327-3336, DOI:10.1002/app.13543

3. Wang X, Li Y, Liao W, Gu J, LĐ D. A new intumescent flame-retardant: preparation, surface modification, and its application in polypropylene. Polymers for Advanced Technologies, 2008, 19,1055-1061, DOI:10.1002/pat.1077

4. Dai J, Li B. Synthesis, thermal degradation, and flame retardance of novel triazine ring- containing macromolecules for intumescent flame retardant polypropylene. Journal of Applied Polymer Science, 2010, 116, 2157-2165. DOI:10.1002/app.31813

5. Jha NK, Misra AC, Bajaj P. Flame-Retardant Additives for Polypropylene. Journal of Macromolecular Science, 2006, 24, 69-116. DOI:10.1080/07366578408069971

6. Atay HY, Çelik E. Size dependence of flame retardant composite coatings reinforced with huntite and hydromagnesite, MSAIJ, 2014, 11, 85-96.

7. Wilkie CA, Morgan AB. Fire Retardancy of Polymeric Materials, 2010, 1-15, ISBN 978-1-4200-8399-6.

8. National Institute of Environmental Health Sciences, www.niehs.nih.gov. Accessed 06.03.2018.

9. Qiu X, Li Z, Li X, Zhang Z. Flame retardant coatings prepared using layer by layer assembly:A review. Chemical Engineering Journal 2018, 334, 108-122. DOI:10.1016/j.cej.2017.09.194

10. Stapleton HM, Klosterhaus S, Eagle S. Fuh J, Meeker JD, Blum A, Webster TF. Detection of organophosphate flame retardants in furniture foam and U.S. House Dust. Environmental Science\&Technology, 2009, 43, 7490-7495. DOI:10.1021/es9014019

11. Dvir H. Optimization of a flame-retarded polypropylene composite. Composites Science and Technology, 2003, 63, 1865-1875. DOI:10.1016/S0266-3538(03)00170-2

12. Hollingbery LA, Hull TR. The thermal decomposition of huntite and hydromagnesite- A review. Thermochimica Acta 2010, 509, 1-11. DOI:10.1016/j.tca.2010.06.012

13. Atay HY, Çelik E. Use of Turkish huntite/hydromagnesite mineral in plastic materials as a flame retardant. Polymer Composites, 2010, 31, 1692-1700. DOI:10.1002/pc.20959

14. Toure B, Cuesta JL, Gaudon P, Benhassaine A, Crespy A. Fire resistance and mechanical properties of a huntite / hydromagnesite /antimony trioxide /decabromodiphenyl oxide filled PP-PE copolymer. Polymer Degradation and Stability 1996, 53, 371-379. DOI:10.1016/0141-3910(96)00100-0

15. Haurie L, Fernandez AI, Velasco JI, Chimenos JM, Lopez Cuesta JM, Espiell F. Synthetic hydromagnesite as flame retardant. Evaluation of the flame behaviour in a polyethylene matrix. Polymer Degradation and Stability. 2006, 91, 89-994. DOI:10.1016/j.polymdegradstab.2005.08.009

16. Hollingbery LA, Hull TR. The fire retardant behaviour of huntite and hydromagnesite -A review. Polymer Degradation and Stability. 2010, 95, 2213-2225. DOI:10.1016/j.polymdegradstab.2010.08.019

17. Weil ED, Levchik SV. Flame Retardants in Commercial Use or Development for Polyolefins. Journal of Fire Sciences. 2008, 26 5-43. DOI:10.1177/0734904107083309

18. Shen KK, Kochesfahani S, Jouffret F. Zinc borates as multifunctional polymer additives. Polymer Advance Technology 2008, 19, 469- 474. DOI:10.1002/pat.1119

19. Oualha MA, Amdouni N, Laoutid F. Synergistic flame-retardant effect between calcium hydroxide and zinc borate in ethylene-vinyl acetate copolymer (EVA). Polymer Degradation and Stability. 2017, 144, 315-324. DOI:10.1016/j. polymdegradstab.2017.08.032

20. Dike AS, Umit T, Dogan M. Influence of zinc borate on flame retardant and thermal properties of polyurethane elastomer composites containing huntite- hydromagnesite mineral. Fire and Materials 2017, 41, 890-897. DOI: $10.1002 /$ fam. 2428

21. Liu J, Zhou K, Tang G, Wang B, Gui Z, Yuen RKK. Synthesis of Co3(HPO4)2(OH)2 nanosheets and its synergistic effect with intumescent flame retardants in ethylene-vinyl acetate copolymer. Polymer Composites, 2018, 39, 238246. DOI:10.1002/pc.23923

22. Tait M, Pegoretti A, Dorigato A, Kalaitzidou K. The effect of filler type and content and the manufacturing process on the performance of multifunctional carbon/poly-lactide composites. Carbon 2011, 49, 4280-4290 DOI: 10.1016/j.carbon.2011.06.009 
23. Ahmad FN, Jaafar M, Palaniandy S, Azizli KAM. Effect of particle shape of silica mineral on the properties of epoxy composites. Composite Science and Technology, 2008, 68, 346-353. DOI:10.1016/j.compscitech.2007.07.015

24. Bishay IK, Abd-El-Messieh SL, Mansour SH. Electrical, mechanical and thermal properties of polyvinyl chloride composites filled with aluminum powder. Materials \& Design. 2011, 32, 62-68. DOI:10.1016/j.matdes.2010.06.035

25. Wu CL, Zhang MQ, Rong MZ, Friedrich K. Silica nanoparticles filled polypropylene: effects of particle surface treatment, matrix ductility and particle species on mechanical performance of the composites. Composites Science and Technology. 2005, 65, 635-645. DOI:10.1016/j.compscitech.2004.09.004

26. Atay HY, Çelik E. Mechanical Properties of Flame Retardant Huntite and Hydromagnesite Reinforced Polymer Composites. Polymer-Plastics Technology and Engineering. 2013, 52, 182-188. DOI:10.1080/03602559.2012.735310

27. Basfar $\mathrm{A}, \mathrm{Bae} \mathrm{HJ}$. Influence of magnesium hydroxide $(\mathrm{MH})$ and huntite hydromagnesite $(\mathrm{HH})$ on mechanical properties of ethyl- ene vinyl acetate (EVA) compounds cross-linked by dicumylperoxide and ionizing radiation. Journal of Fire Sciences. 2010, 28, 161-180. DOI: 10.1177/ 0734904109340765.

28. Vladimirov V, Betchev C, Vassiliou A, Papageorgiou G, Bikiaris D. Dynamic mechanical and morphological studies of isotactic polypropylene/fumed silica nanocomposites with enhanced gas barrier properties. Composites Science and Technology. 2006, 66, 2935-2944.

29. Yetgin SH, Ünal H, Mimaroğlu A. Findik F. Influence of process parameters on the mechanical and foaming properties of PP polymer and PP/TALC/EPDM composites. Polymer-Plastics Technology and Engineering. 2013, 52, 433-4439. DOI: $10.1080 / 03602559.2012 .748802$

30. Akil HM, Lily N, Razak JA, Ong H, Ahmad ZA. Effect of various coupling agents on properties of alumina-filled PP composites. Journal of Reinforced Plastics and Composites. 2006;25(7):745-759. DOI:10.1177/0731684406062068

31. Savas LA, Deniz TK, Tayfun U, Dogan M. Effect of microcapsulated red phosphorus on flame retardant, thermal and mechanical properties of thermoplastic polyurethane composites filled with huntite\&hydromagnesite mineral. Polymer Degradation and Stability. 2017, 135, 121-129. DOI:10.1016/j.polymdegradstab.2016.12.001

32. [32]. Ferna'ndez AI, Haurie L, Formosa J, Chimenos JM, Antunes M, Velasco JI. Characterization of poly(ethylene-co-vinyl acetate) (EVA) filled with low grade magnesium hydroxide. Polym. Degrad. Stabil. 2008, 94, 57-60.

\section{Badania właściwości ogniochronnych boranu cynku w obecności huntitu i hydromagnezytu w kompozytach polimerowych}

Pożary od wieków stanowia zagrożenie dla ludzi. Gdy ludzie stracili życie i mienie w wyniku pożarów, próbowali zwalczyć pożar, a ich wysiłki w tej dziedzinie byly coraz bardziej skuteczne Niestety, nadal nie jest możliwe całkowite wyeliminowanie ryzyka rozpoczęcia pożaru. Ważne jest ugaszenie pożaru natychmiast po wybuchu aby uratować ludzkie życie. Naukowcy pracuja w tej dziedzinie w ostatnich latach; koncentrują się na wytwarzaniu materiałów ognioodpornych przy użyciu różnych surowców. Można to zapewnić na różne sposoby; albo materiał ognioodporny może być wytworzony jako nowy, albo ognioodporność może być zapewniona przez włączenie materiału dodatkowego do materiału łatwopalnego. W badaniach używano minerałów huntite $i$ hydromagnesitu, aby nadać materiałom polimerowym właściwości ognioodpornych, osiagając bardzo udane wyniki. W artykule przedstawiono wyniki wykorzystania mineratów huntitu i hydromagnezytu w obecności boranu cynku w kompozytach polipropylenowych w celu zwiększenia właściwości ognioodpornych materiałów polimerowych. Różne ilości minerałów zmieszano z polipropylenem, a kompozyty wytworzono za pomoca wytłaczarki dwuślimakowej w celu zaobserwowania efektu synergicznego. Przeprowadzono analizy skaningowej mikroskopii elektronowej (SEM) w celu określenia właściwości strukturalnych i morfologicznych kompozytów. Właściwości termiczne określono za pomoca analiza termograwimetryczna (TGA). Przeprowadzono próby rozciagania i zginania trzypunktowego $w$ celu określenia właściwości mechanicznych. Działanie zmniejszające palność oceniono zgodnie z testem palności w pionie UL 94. Stwierdzono, że uzyskano bardzo dobre efekty synergiczne, boran cynku miał znaczacy wplyw na huntit i hydromagnezyt $i$ zmiane charakterystyki palności kompozytów, ponieważ obserwuje się podwyśzone powstawanie węgla drzewnego przy dodawaniu boranu cynku. Ponadto boran cynku zmniejszył ilość dymu powstający podczas spalania

Słowa kluczowe: uniepalniacz, hydromagnezyt huntitu, boran cynku, polipropylen, właściwości mechaniczne, degradacja termiczna, efekt synergiczny 